\title{
Impact of epoxy resin modification on its strength parameters
}

\author{
Andrzej Szewczak \\ Department of General Construction; Faculty of Civil and Architecture; Lublin University of Technology; \\ Nadbystrzycka 40, 20-618 Lublin, Poland; \\ a.szewczak@pollub.pl; ORCID: 0000-0001-5933-0483
}

\begin{abstract}
Modifications of polymer composites are one of the fastest developing fields of technology. Research is focused on two directions: obtaining new composites or modifying existing materials. The first group of tests uses methods for preparing new chemical formulas of polymers containing, as the main structural element: carbon (organic polymers) or silicon (inorganic polymers). In the second group, the research consists in seeking methods to modify the properties of polymers. In building construction, among the others types, the glues (adhesive polymers) are used. They are exerted to connect materials with different physical and mechanical properties. Under the influence of the factor initiating the crosslinking reaction (hardener or temperature), the polymers obtain a solid form. The strength of the glued joint depends on the initial parameters of the glue resin and the target substrate of its application. The glued surface is usually the weakest element in this connection in terms of the possibility of damage due to the effects of loads, therefore methods to improve the strength parameters of adhesives are sought.

The study presents the results of own research on methods of modification of a selected epoxy resin used in the technique as a glue. In order to ensure effective mixing of the adhesive with the fillers, ultrasound energy was used. After the resin had hardened, tests were carried out to determine the hardness and tensile strength of the obtained composites. Based on the results, SEM analysis and observation of the effect of ultrasound, the phenomena affecting the changes in the above mechanical properties were explained.
\end{abstract}

Keywords: epoxy resins, microsilica, carbon nanotubes, ultrasound

\section{Introduction}

Polymers are substances and chemical compounds based on cyclically repeating, single chemical sequences of atoms (so-called mers) and forming polymer chains [1][2]. In polymer chains structures, atoms and their individual sequences are connected with each other by means of different types of chemical bonds: ionic, coordination, polarized or hydrogen [2][3]. Depending on the chemical composition and type of existing bonds, polymers can have specific assignments. In the technique sciences, the usefulness of the polymer - epoxy adhesive in this paper/case - is determined by rheological, physic and mechanical properties: viscosity, final adhesion to the substrate, (concrete, steel) [4][5][6], hardness, tensile strength. Viscosity determines the possibility of spreading the adhesive on the target surface, filling the unevenness of the substrate with the glue and, finally, the adhesion of the resin after hardening. However, the durability of the glued connection depends on the adhesion of the resin after the crosslinking reaction and its resistance to loads. The process of the curing reaction largely depends on the presence of specific 
polymer groups (phenolic, epoxy, ester), the type of reaction initiating factor (hardener/ temperature) and the addition of possible substances (fillers) [1] [2] [3]. Polymer-based building glues harden after only a few hours, and after 2 days, they usually achieve full adhesion to the substrate [1].

The epoxy resins are oligopolymers which are reaction products of epichlorohydrin and bis-phenol [1] [2] [7]. Except for many favorable adhesive and strength properties, their additional features are: chemical resistance, non-absorption and dielectricity. The disadvantages include: low resistance to high temperatures and UV radiation.

The fillers this is a group of additives by means of which it is possible to obtain specific, other than initial, properties of resins [8]. Their quantity and type are selected due to the type of planned modification, polymer chemical composition, properties of filler particles (shape, chemical composition, specific surface) and the required final effect. Various substances are used as fillers, most often in the form of powders or liquids [9][10][11]. The role of the filler is also fulfilled by materials from the recycling process e.g. rubber, minced rock. The filler particle size is selected based on the known particle size of the polymer chain (nano- and microparticles). [12][13] The amount of filler usually depends on the weight of the resin (volumetric dosing is less accurate due to the change of resin density with temperature changes). In order to ensure regular and effective distribution of the filler in the volume of resin, in the technology of polymers the ultrasound are used [14][15][16][17]. Dynamic phenomena caused by ultrasound (high frequency vibrations, cavitation, pressure and temperature changes) cause the formation of temporary atomic bonds between the filler particles and the polymer chains. The degree of connection of the filler particles with the polymer and the filling of voids between the branches of the chain affects the mechanical properties of the hardened polymer. Then, the glue subjected to the hardening process obtains proper adhesion to the substrate.

The following paper presents the results of own research on the possibility of using epoxy resin modified with two fillers - microsilica and carbon nanotubes to improve the physical and mechanical properties of the glue. Exact mixing of fillers with the resin was achieved by the action of ultrasonic energy. The study contains results of research on the impact of fillers on the mechanical and strength properties of obtained composites - hardness and tensile strength. The tests were one of the stages of determining the impact of this kind of modification method thus adopted on the final adhesion of the adhesive to the substrate. The main reason in favor of the chosen topic is the lack of literature and research results focused on this type of modification in relation to epoxy resins. Microsilica is generally used in cement composites, nanotubes are widely used in electrical engineering and mechanics. Ultrasounds are abused as a factor which is activating the chemical sonoreactions [1]. The adopted method of changing resin parameters affects all their performance properties. In [16] [17] the results of research on rheological and adhesive properties are presented. It has been shown how ultrasound and fillers affect the viscosity, temperature and adhesive parameters (free surface energy measured by the Owens-Wendt method was used as the factor describing the adhesion of resin to the substrate). In order to accurately explain the effects caused by the introduced changes, SEM analysis was used. Obtained test results constituted the basis arguments for determining the effectiveness of the applied modifications in relation to their practical application, e.g. for reinforcing reinforced concrete structures or gluing the concrete elements. This is important from the point of view of striving to extend the durability of building structural elements by strengthening them. 


\section{Materials, devices and methodology of research}

For the tests the Epidian 52 epoxy resin was used, by means of which it is possible to glue concrete, ceramics, wood or metal elements. Its basic parameters are:

- form/color - thick, yellow - brown liquid with a characteristic smell,

- flash point $-64^{\circ} \mathrm{C}$,

- gel time (hardener Z-1) - 40min

- epoxy number [mol / 100g]: $0.51-0.55$,

- density (at $\mathrm{T}=22^{\circ} \mathrm{C}$ ): $1.12-1.13 \mathrm{~g} / \mathrm{cm}^{3}$,

- viscosity $\left(\mathrm{T}=22^{\circ} \mathrm{C}\right): 400-800 \mathrm{mPa} \cdot \mathrm{s}$,

- solubility: insoluble in water, soluble in ketones, esters, alcohols, aromatic hydrocarbons

- hardener: Z1 (triethylene tetrachloro amine)

The fillers used are: microsilica and carbon nanotubes. The amount of filler, determined experimentally, was related to the weight of the resin. The formulas of the tested composites are presented in table 1.

Table 1. Resin formulas used in research

\begin{tabular}{lllll}
\hline $\begin{array}{l}\text { Number } \\
\text { of series }\end{array}$ & Series designation & Type of modification & Amount of filler [\%] $\begin{array}{l}\text { Amount } \\
\text { of hardener [\%] }\end{array}$ \\
\hline 1 & EP52 & ------------ & ---------- & 7.6 \\
\hline 2 & EP52+UD & sonication & --------- & 7.6 \\
\hline 3 & EP52+Mk & sonication + microsilica & 0.5 & 10 \\
\hline 4 & EP52+NR & $\begin{array}{l}\text { Sonication and carbon } \\
\text { nanotubes }\end{array}$ & 0.1 & 10 \\
\hline
\end{tabular}

In the first stage of research, the initial parameters (viscosity and density) of unmodified resin at the temperature of $22^{\circ} \mathrm{C}$ were determined. Then the adhesive was subjected to three types of modification presented in table 1 . The same time of ultrasound duration ( $3 \mathrm{~min}$ ) was adopted for each recipe (the duration and power of ultrasound was determined experimentally based on observation and measurements of the temperature and resin viscosity). Due to the effect of ultrasound, consisting in heating the resin, further tests related to the preparation of the samples were carried out when the resin reached the initial temperature of $22^{\circ} \mathrm{C}$. For hardness tests, samples were made in the form of discs with a diameter of $10 \mathrm{~cm}$ and a thickness of $1 \mathrm{~cm}$ (Fig. 2a). For testing strength properties, paddle-shaped samples were made (Fig. 2b), in accordance with Standards [18][19][20].

The UP 400S stationary sonicator emitting $24 \mathrm{kHz}$ waves with adjustable power range from 0 to $400 \mathrm{~W}$ was used as the source of ultrasound. Fig. 1 shows a test stand for applying modifications and measuring viscosity. 


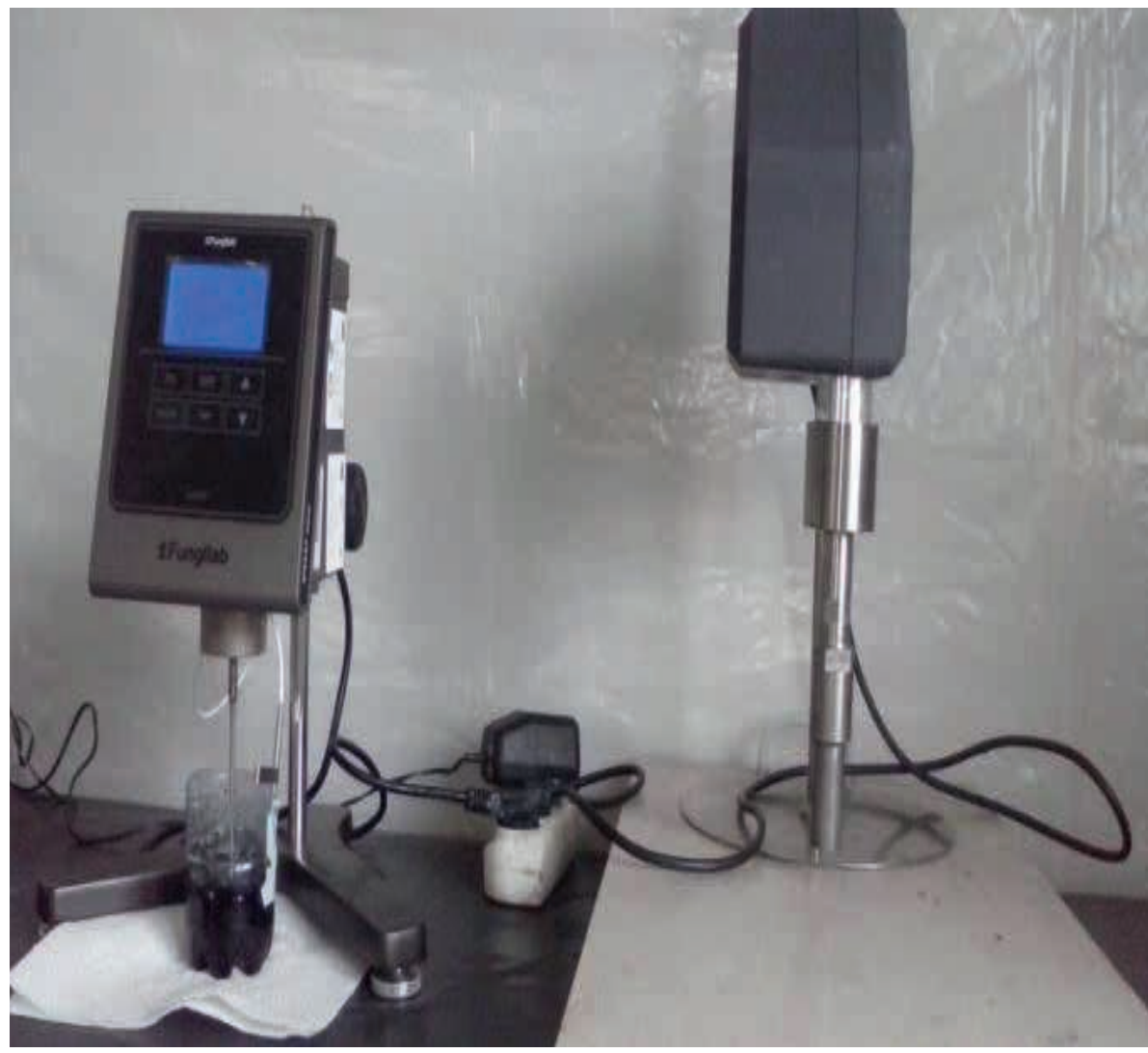

Fig. 1. Sonicator UP 400S (Andrzej Szewczak)
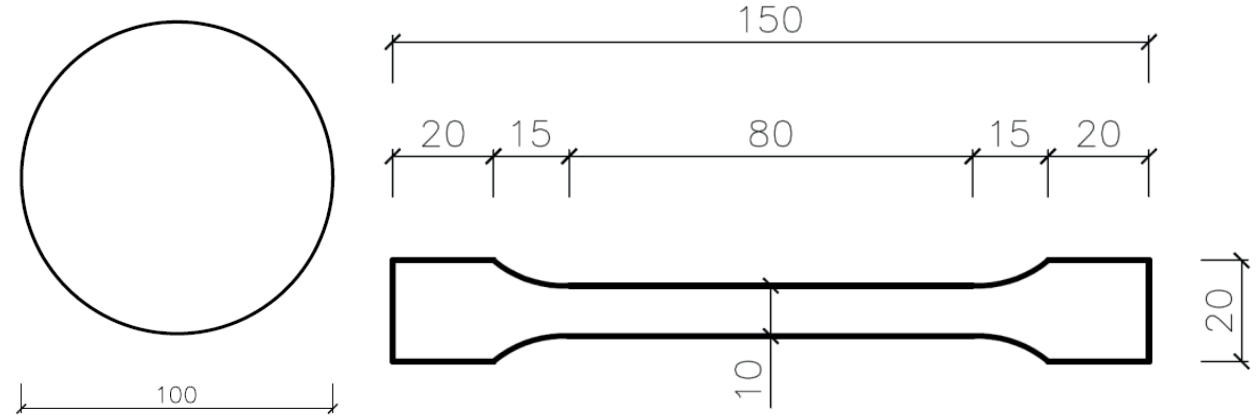

A

Fig. 2. Test specimen dimensions a) hardness, b) tensile strength (Andrzej Szewczak)

The hardness of the resins was tested using the Vickers method on a Zwick - Roell device assuming a base load of $10 \mathrm{~N}$, and the diamond-shaped tip. Tensile strength tests were carried out on the MTS 810 testing press machine with an additional device with a load range up to $5 \mathrm{kN}$. All tests were carried out 14 days after sample formation and resin hardening. The end point of the research was SEM analysis to determine the changes in the internal structure of 
the resins after the modifications carried out. All samples were stored in temperature $22^{\circ} \mathrm{C}$ in the time between their performance and research.

During sample preparation, it is important to follow several principles contained in the test Standards [18][19][20]. Paddle-shaped samples with specific dimensions must be subjected to mechanical pre-treatment to determine their uniform thickness of $4 \mathrm{~mm}$, which necessitates the abrasion of the original surface layer (Fig. 3).

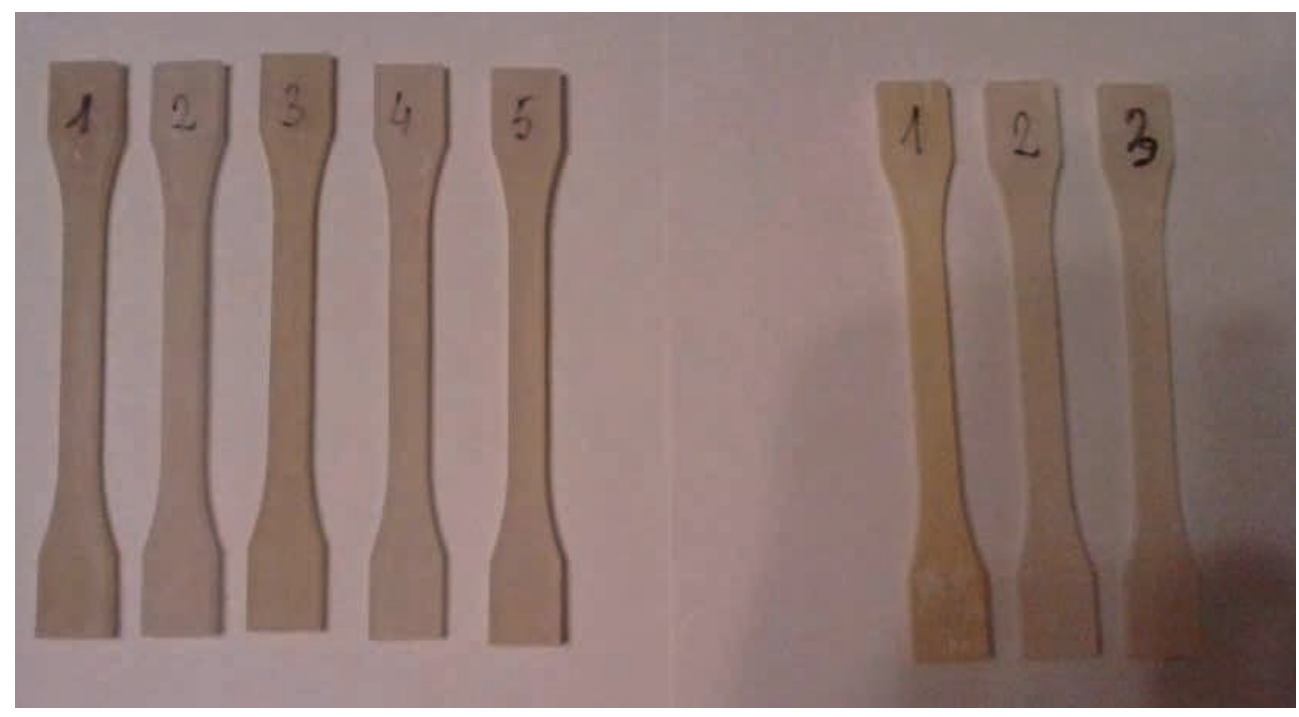

Fig. 3. Samples after the machining before tensile testing. (Andrzej Szewczak)

\section{Results and conclusions}

Table 2. The test results of resin mechanical properties, *results from [16] [17]

\begin{tabular}{lllll}
\hline Series & 1 & 2 & 3 & 4 \\
\hline Hardness HV10 & 20.35 & 21.4 & 20.6 & 21.03 \\
\hline Standard deviation & 0.9 & 0.5 & 0.6 & 0.7 \\
\hline Tensile strength $\mathrm{f}[\mathrm{MPa}]$ & 36.97 & 42.53 & 29.67 & 29.44 \\
\hline Standard deviation & 1.32 & 1.35 & 2.18 & 1.15 \\
\hline Viscosity* $[\mathrm{mPa} \cdot \mathrm{s}]$ & 665.6 & 758.4 & 585.6 & 1977.6 \\
\hline Free surface energy* $[\mathrm{mPa} \cdot \mathrm{s}]$ & 65.43 & 72.43 & 72.6 & 64.43 \\
\hline
\end{tabular}

Obtained test results, considered together with the results presented in $[16,17]$ indicate fundamental differences in the mechanical properties of the described composites. Based on the research the following conclusions were made:

1. The modification method has a direct impact on the properties of the outer surface and the internal structure of the adhesive layer. Considering the viscosity (the parameter determining the adhesion of the non-hardened resin to the concrete substrate) and free surface energy (the parameter describing the adhesion of the resin to the substrate after its hardening), it was noticed that ultrasound causes the break of the primary structure of the polymer chains. In this way, free ends of mers are formed (Fig. 4 b), which can directly connect to the substrate or to filler particles, depending on its chemical nature. 
2. The data presented in Table 2 show that the differences in the hardness of the resins (hardness is measured on the external surface) are small, at the limit of $1-5 \%$, with the most favourable value for series 2 . The addition of fillers significantly changed the obtained results. Also taking into account the viscosity results of the modified resins, each modification used should be considered separately. For the second series, it should be noted that the increase in $\mathrm{ft}$ value is due to disorganization of the adhesive structure during preparation of the resin under ultrasonic conditions. Re-crosslinking of the polymer structure after adding the hardener results in better distribution and packing of unit molecules and reduction of the distance between the chains.
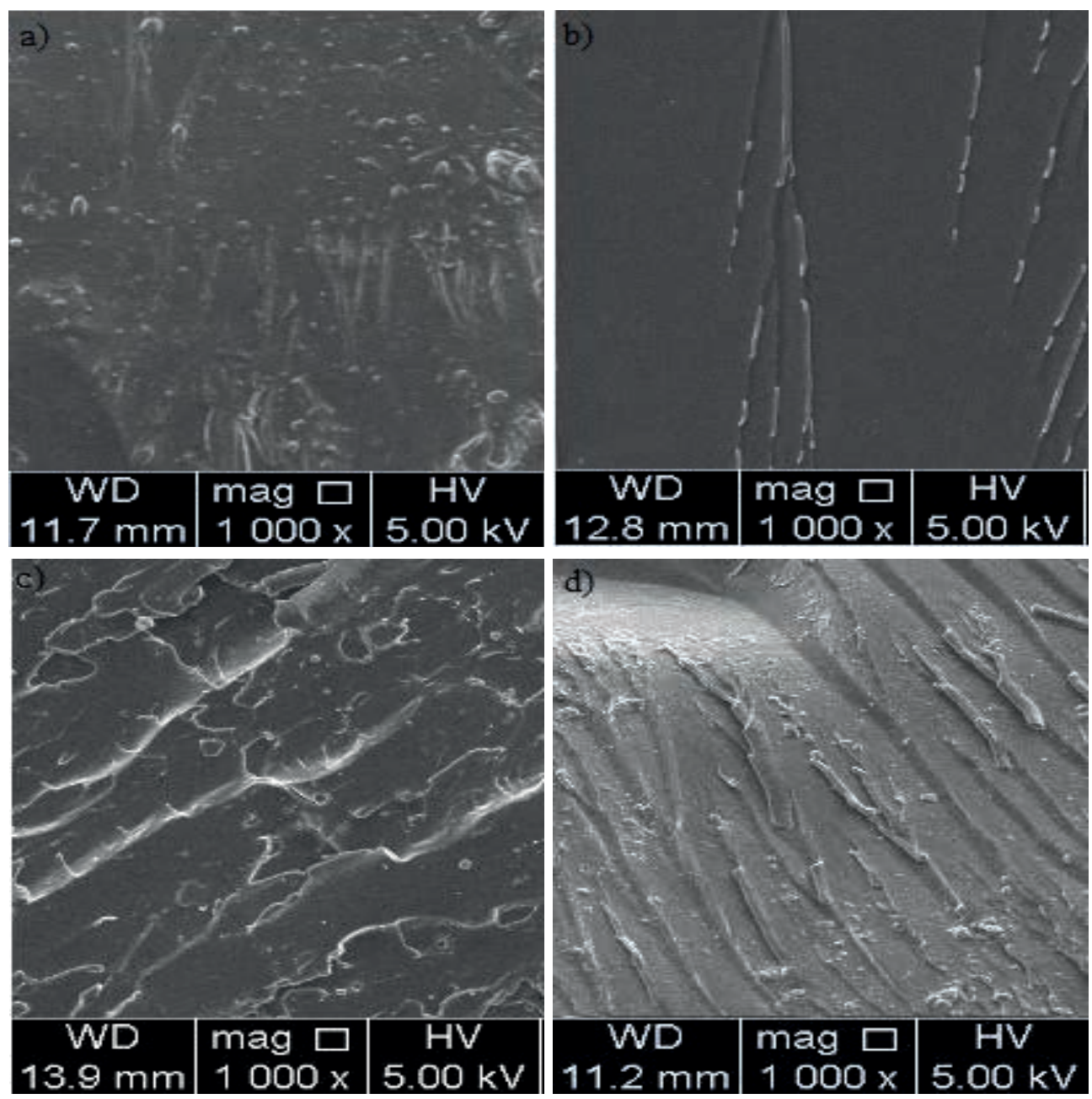

Fig. 4. SEM images of individual series of samples a) EP52, b) EP52+UD, c) EP52+Mk, d)EP52+NR (Andrzej Szewczak)

3. The addition of microsilica reduces the initial tensile strength. This is due to the introduction of spherical microsilica particles into the space between individual mayors. Considering the HV10 hardness results for this series, it was found that the outer layer, 
which is in direct contact with the substrate, has an increased amount of microsilica particles that strengthen the external structure of the resin layer. However, their number in the internal structure is smaller. The connections between mers become less durable, but the material does not lose its deformability, it becomes more plastic.

4. For the last EP + NR series, with the addition of carbon nanotubes, it was found for similar conclusions, taking into account a few differences. Nanotubes, whose basic component is carbon, are more chemically compatible with polymer chains, they also have a similar branched structure during decomposition caused by ultrasound energy. Some connections between polymer chains are bound by nanotube particles, which makes them weaker than in series 1 without the addition of fillers. It is worth noting, however, that due to the large specific surface area of the nanotubes, the internal structure of the adhesive is compacted. At the same time, a similar phenomenon was observed as in the case of the EP52 + MK series - some nanotubes are concentrated on the surface layer of the adhesive, which does not cause significant changes in the hardness value.

\section{Podsumowanie}

At this stage of testing, it is already known that no explicit comparison and evaluation of composites should be carried out with only laboratory results in mind. They should also be referred to the conditions under which the gluing will occur (actual temperature, humidity), the required final effects, the type of glued materials and the parameters of the target surfaces, e.g. roughness. A similar research process can be applied to other construction adhesives, containing e.g. mineral fillers. The resin modified only by ultrasound, i.e. the modification method relatively easy to perform, obtained the best results for both adhesive and strength parameters. The addition of the described fillers has reduced the tensile strength, but taking into account the fact that the resin achieves the greatest adhesion in a thin layer of contact with the ground, this kind of modifications should not be rejected in advance. The addition of microsilica can improve the adhesion of the adhesive under conditions of lower real temperature at the time of its dispensing, and nanotubes may increase this adhesion at high temperature.

\section{Acknowledgements}

The research was financed from the funds awarded under the "Young Academic Staff 2017" subsidy.

\section{References}

[1] Rabek J. F., Modern knowledge about the polymers, PWN, Warsaw 2015

[2] Florjańczyk Z., Penczek S., Polymer chemistry. Basic synthetic polymers and their applications, Warsaw University of Technology Publishing House, vol. 2, Warsaw 2001.

[3] Ehrenstein G. W., Brocka - Krzemińska Ż., Polymer materials: structure, properties, application, PWN, Warsaw 2016.

[4] Sadowski Ł., Czarnecki S., Hoła J., 2016, "Evaluation of the height 3D roughness parameters of concrete substrate and the adhesion to epoxy resin", International Journal of Adhesion and Adhesives, vol. 67, 2016, pp. 3 - 13. https://doi.org/10.1016/j.jjadhadh.2015.12.019

[5] May I., Clayton A., Epoxy resins. Chemistry and Technology, Marcel Dekker Inc., New York, 2018.

[6] Lokensgard E., Industrial Plastics. Cengage Learning, Eastern Michigan University, Ypsilanti, Michigan, 2016. 
[7] Fang-Long J., Xiang L, Soo-Jin P., "Synthesis and application of epoxy resins: review", Journal of Industrial and Engineering Chemistry, vol. 29, pp. 1-11, 2015, https://doi.org/10.1016/j. jiec.2015.03.026

[8] Wypych G., Handbook of fillers. ChemTech Publishing, Toronto, 2016.

[9] Teh P.L. et al., "The properties of epoxy resin coated silica fillers composites", Materials Letters, Vol. 61, Issues 11-12, 2007, pp. 2156-2158. https://doi.org/10.1016/j.matlet.2006.08.036

[10] Park J. S., Jin. F-L., “Thermal properties of epoxy resin/filler hybrid composites”, Polymer Degradation and Stability, vol. 97, issue 11, 2012, pp. 2148-2153. https://doi.org/10.1016/j. polymdegradstab.2012.08.015

[11] Chikhi N., Fellahi S., Bakar M., "Modification of epoxy resin using reactive liquid (ATBN) rubber", European Polymer Journal, vol. 38, issue 2, 2002, pp. 251-264. https://doi.org/10.1016/ S0014-3057(01)00194-X

[12] Sprenger S., "Epoxy resins modified with elastomers and surface-modified silica nanoparticles", Polymer, vol. 54, nr 18, pp. 4790 - 4797, 2013. https://doi.org/10.1016/j.polymer.2013.06.011

[13] Nakamura Y. et al., "Effects of particle size on mechanical and impact properties of epoxy resin filled with spherical silica", Journal of Applied Polymer Science, vol. 45, issue 7, pp. 1281 - 1289, 1992. https://doi.org/10.1002/app.1992.070450716

[14] Fic S., Szewczak A., Barnat - Hunek D., Łagód G., 2017, "Processes of fatigue destruction in nanopolymer-hydrophobised ceramic bricks", Materials, no 1, vol. 10, 2017. https://doi.org/10.3390/ ma10010044

[15] Fic S., Szewczak A., Kłonica M., 2015, Adhesive properties of a low molecular weight polymer modified with nanosilica and disintegrated with ultrasounds for hydrophobization of building ceramics, Polimery, vol. 11-12, pp. 730-734, 2015, https://www.doi.org/10.14314/polimery.2015.730

[16] Szewczak A., Szeląg M., Modifications of epoxy resins and their Influence on their viscosity, in: IOP Conference Series: Materials Science and Engineering, vol. 471, s. 1-9, 2019, doi: https://www.doi.org/10.1088/1757-899X/471/2/022038

[17] Szewczak A. Szeląg M., Viscosity and free surface energy as parameters describing the adhesion of the epoxy resin to the substrate, IOP Conference Series: Materials Science and Engineering., vol. 484, nr 1, s. 1-7, 2019, doi: https://www.doi.org/10.1088/1757-899X/484/1/012003

[18] PN-EN ISO 3673-2:2012, Plastics - Epoxy resins - Part 2: Preparation of test pieces and determination of properties

[19] PN-EN ISO 527-1. Determination of mechanical strength at static tensile. General rules.

[20] PN-EN ISO 527-2. Determination of mechanical strength at static tensile. Plastic testing conditions.

\title{
Wpływ modyfikacji żywic epoksydowych na ich parametry wytrzymałościowe
}

\author{
Andrzej Szewczak \\ Katedra Budownictwa Ogólnego, Wydziat Budownictwa i Architektury, Politechnika Lubelska \\ Nadbystrzycka 40, 20-618 Lublin, Polska; \\ a.szewczak@pollub.pl; ORCID: 0000-0001-5933-0483
}

Streszczenie: Modyfikacje kompozytów polimerowych to jedna z najszybciej rozwijających się dziedzin techniki. Badania skupiają się na dwóch kierunkach: uzyskiwaniu nowych materiałów lub modyfikacji materiałów już istniejących. W pierwszej grupie badań stosuje 
się metody sporządzania nowych wzorów chemicznych polimerów, zawierających główny pierwiastek strukturalny: węgiel (polimery organiczne) lub krzem (polimery nieorganiczne). W grupie drugiej badania polegają na poszukiwaniu metod modyfikacji właściwości polimerów. W budownictwie stosowane są m.in. są kleje (polimery adhezyjne). Wykorzystywane są do łączenia materiałów o różnych właściwościach fizyko - mechanicznych. Pod wpływem działania czynnika inicjującego reakcję sieciowania (utwardzacze lub temperatura) polimery uzyskują formę stałą. Wytrzymałość złącza klejonego zależy od parametrów wyjściowych kleju i docelowej powierzchni jego stosowania. Ponieważ takie złącze jest zazwyczaj najsłabszym elementem, to poszukuje się metod mogących pomóc w poprawieniu parametrów wytrzymałościowych klejów. W opracowaniu przedstawiono wyniki badań własnych nad sposobami modyfikacji wybranej żywicy epoksydowej stosowanej w technice jako klej. W celu zapewnienia skutecznego wymieszania kleju z wypełniaczami zastosowano energię ultradźwięków. Po stwardnieniu żywicy przeprowadzono badania mające na celu ustalenie twardości i wytrzymałości na rozciąganie uzyskanych kompozytów żywicznych. Na podstawie wyników, analizy SEM oraz obserwacji efektu działania ultradźwięków wyjaśniono zjawiska wpływające na zmiany w/w cech mechanicznych.

Słowa kluczowe: żywice epoksydowe, mikrokrzemionka, nanorurki węglowe, ultradźwięki 
